\title{
The Canadian Penal Press: A Documentation and Analysis
}

Robert Gaucher

The penal press is a world-wide phenomenon which reached the height of its achievement in the 1950s and 1960s, particularly in North America. A survey taken in the United States in 1959 found that there were more than 250 penal press publications in Canada and the United States, reaching an estimated readership of two million (Collins Bay Diamond, January, 1959). Russell Baird (1967), in his study The Penal Press (which focuses exclusively on the United States), discovered that the penal press started in the late nineteenth century, with Summary (1883) from Elmira Reformatory in New York State laying claim to being the first publication. It was followed by Our Paper (1885), Massachusetts Correctional Institution at Concord, and Prison Mirror (1887) of the Minnesota State Penitentiary at Stillwater (Baird, 1967). ${ }^{1}$ The Canadian penal press officially came into being on September 1, 1950 with the publication of Kingston Penitentiary's Telescope. Since then there have been more than one hundred separate penal publications produced and published by prisoners in Canada's federal penitentiaries.

I have read and subscribed to numerous penal press publications since the early 1960s, but did not give them the serious consideration they are due until recently. My new interest was spurred by my doctoral research into the history of Canada's penitentiary system, and the dearth of available documentation which provides an account of the experiences of criminalization and incarceration from the perspective of those subjected to it. While working on my reconstruction of the history of the development of Canada's prison system (See Gaucher, 1982; Gaucher, 1987), I came to readily accept the arguments of historians such as George Lefebvre (1949) and George Rude (1970) concerning the necessity of taking into account what they refer to as "history from below". In my research I discovered neither organised sources nor analytic texts which addressed this aspect of Canadian criminal-justice in its formative years, and I would argue that the same situation holds for the contemporary post World War II period. My interest has also been heightened by pedagogical concerns. Frustrated by having to rely on sensational commercial work by writers like Roger Caron (1978) and Steven Reid (1986), or specious academic products whose editors force feed prison writers to reproduce the editors' perspectives and 
prejudices (See Adelberg and Currie, 1987), I had almost given up assigning such ethnographic reading to criminology students. 2 Upon re-examining some of the penal press publications I had accumulated over the years or currently receive, it became clear that they constituted an exceedingly rich ethnographic source of prisoner experience and prison life in Canada during the post-war period of prison reform and change.

A distinction needs to be made between what I define as "outside directed magazines" and "inside directed or joint magazines". Outside directed magazines are intended to serve as a means of communication with the Canadian public, and therefore feature analysis of contemporary criminal-justice issues and serious prose on the experience of criminalization, incarceration and recidivism. Joint magazines are directed at the population of a particular prison and focus on reporting institutional activities such as sports, social events and club endeavors, and on providing information on new programs and legislation, coming events and internal news. Both provide insight into the perspectives and understanding of prisoners and the everyday experience of prison life in Canada.

In the outside-directed publication, one can trace prisoners' views on the whole post World War II program of prison reform and expansion, on changes in social control legislation and its implementation, and on the major problems and concerns that dominate their lives while in prison and after release. For example, one can trace the history of the parole board, from its initial proposal and eventual creation through its changes and adjustments up to the present. It is possible through these publications to discover the central issues debated and to gain an insight into prisoners' perceptions, conclusions and recommendations vis-a-vis conditional release. Within these publications as a whole, one also discovers the burning issues of responsible prison editors and writers over the past four decades. In the $1950 \mathrm{~s}$, a major theme was the problem of juvenile delinquency, and prison writers expressed strenuous opposition to the incarceration of youthful offenders in maximum security (warehouse) penitentiaries. Another major focus was on penal reform programs and vocational and educational training. Through their press, prisoners lobbied on the prison reform issue, in an attempt to gain public and official recognition of the need to reaffirm and go forward with newly developed programs. The problems of post-release, the stigmatization of a prison record and the need for post-release facilities and work opportunities for the released "reformed convict" -- were also addressed. More localized concerns were also thoroughly debated in these journals. For 
example, British Columbia Penitentiary's Transition (1951-1966) often focused on the area of drug addiction, drug legislation, the legalization of drug use (following the British model of that period), and the use of the Habitual Criminal Act to control drug users.

Even the strictly "joint magazine" provides (in total) a fertile insight into the everyday activities of prison life and prisoners' concerns and problems. One also gets a sense of the "temper and feel" of a particular penal institution through its publications. For example, Warkworth Institution's The Outlook (1972-1989) presents an image of a tightly controlled institution in which the inmates are somewhat subservient and pliable to the authority of the staff and administration, while publications from Millhaven Penitentiary (e.g., Odyssey, 1978 1982) reflect the high level of tension, despair, and opposition which has characterized that institution's history.

Special publications produced by specific prisoner groups (and speaking only for those groups) such as Native Brotherhood groups, Lifers' Groups, or Alcoholics Anonymous groups, provide a particular perspective on criminal-justice and correctional issues. They also reflect the historical changes that characterize Canadian society in this period. In this regard, I have found the publications of Native Brotherhood groups to be particularly interesting. As the people of Canada's First Nations' perception of their role and social situation changed in the containing society, these changes were reflected in the move towards traditional ways, and spiritual understanding amongst Canada's large incarcerated Native population. The history of the Native Brotherhoods and Sisterhoods in Canada's penitentiaries can be researched through the penal press, and in doing so one encounters many outstanding Native leaders, such as Malcolm Norris (Dobbin, 1981) and Art Solomon who were instrumental in their development. ${ }^{3}$

\section{CANADIAN MEMbERShip IN THE INTERNATIONAL PENAL PRESS}

The penal press and its exchange network was a major international phenomenon in the 1950s and 1960s. The legacy of this phenomenon is apparent in the continuation of the penal press today. While the centre of interest was the United States and Canada, most European nations (including Soviet block countries), Australia, New Zealand, Latin American and Far Eastern nations had prisons which published magazines as members of the International Penal Press network. Membership in the International Penal Press was a dominating factor throughout these two decades, providing direction, form and encouragement to prison writers and editors throughout the network, and acting as an unofficial but highly influential censor. A publication was not a success until it was formally recognized within 
the penal exchange columns of the network's publications, and many new magazines or new editorial staffs waited anxiously for the network's approval or disapproval. Publications which were "too supportive" of prison regimes and administrations, those which were too bitter and cynical, or those which simply did not meet the demanded standards of quality (demeaning rather than raising the public's view of prisoners) were openly censured in the penal exchange columns. 4 To receive wide-spread recognition was the ultimate sign of success, as was the reprinting of outstanding articles in fellow penal press publications. Canadian penal press publications were no exception to this rule, and until the demise in the late 1960s of the principal magazines from Canada's maximum security penitentiaries, Canadian publications were staunch members of this network.

The Canadian penal press peaked in the 1950s, with widespread outside distribution. Kingston Penitentiary's Telescope (1950-1968) was the forerunner of penal publications here, establishing the credibility needed to gain official support -- and it was strongly supported by Penitentiary Commissioner R. B. Gibson and his office. After publishing for six months within the institution (September 1959 to February 1951), it was allowed to solicit outside subscribers. By June 1951 it had 625 outside subscribers, which grew to 1,500 paid subscribers by June, 1958. The Kingston Prison for Women provided columns, articles, and poetry from January 1951 and editorial staff from May 1952 until the mid-1960s. The success of Telescope opened the door to publications from all the remaining penitentiaries, with the exception of The Kingston Prison for Women. Saskatchewan Penitentiary's The Pathfinder (February 1951) was the second subscribed magazine, followed closely by British Columbia Penitentiary's Transition (March 1951), Ste. Vincent de Paul's Pen-O-Rama (May 1951), Dorchester's The Beacon (July 1951) and Stony Mountain Penitentiary's Mountain Echo (September 1951) and the Collins Bay Diamond (January 1952). This is the roster of publications that firmly established the penal press tradition in Canada. Each with its own individual style and focus, they ably represented Canada in the international network. Next to Telescope,Pen-O-Rama (1951-1968) was the most successful, by 1958 having a paid subscribers list of 4,000 and numerous outside advertisers. A fully-bilingual magazine (all articles translated), it is noted for its outstanding prose on prison life and serious treatment of criminal-justice and penology issues. 5 Like all of these Canadian publications, it benefited from the stability and continuity of its editorial staff and their serious commitment to the standards of the International Press. Except for The Beacon (1951- 
1971), all were printed in institutional print shops as adjuncts to vocational training programs, giving the high quality writing within their pages a high quality presentation.

The importance of stable, continuous editorial groups needs to be stressed, for this stability enabled staff to learn their trade and maintain the quality that developed over a long period of time. These Canadian publications clearly reflect the high standards and abilities of their staffs. Mentioning only a few: Gord Marr, Cliff Bastine and Sam Carr of the first editorial group of Telescope, Vladimir Nekrassoff of Pen-o-Rama, Gus Constantine and Lyle Jennings of The Pathfinder, Blondy Martin and Gord Thompson of Transition, Tony Ricardo of The Beacon (whose eight plus consecutive years as editor, 1953-1960 is the record), W. Lake and Bud Winters of Mountain Echo, and Nancy Ward-Armour of Tightwire. Outstanding writers and poets such as Doug Bevans, Harvey Blackstock, Frank Guiney, G. Hjalmarson, Steve Reid and George Watson all appear in these pages, ${ }^{6}$ as do outside supporters of note such as Earle Stanley Gardner, whose eloquent support of the penal press in other publications was constantly reprinted in the International Penal Press. ${ }^{7}$ The widespread distribution of these publications and the support of public figures like Gardner heightened media attention and the Canadian penal press was acknowledged, refuted, and analyzed in the outside media throughout this period. Some of Canada's major penal reformers were also enthusiastic supporters, and spokespersons such as Alex Edmison figure prominently in these publications.

The problems facing editorial staff were and are considerable. Confined by the isolation of incarceration, faced with the prospect of pleasing both administration and fellow prisoners, constrained by often unintelligible censorship demands, and in the first two decades, by the prospect of being panned throughout the penal press network, editors had to walk a tightrope of conflicting demands and expectations in a situation where failure could have serious personal consequences. As long as the right tone was attained, one which pleased the Commissioner's office, prison administrators and prison populations, the continuity of staff and publication required to maintain a quality product was forthcoming. This held throughout the 1950 s, but changes in the mid-1960s spelled the end of this golden era of the penal press in Canada.

\section{History AND DEVELopment of THE CANAdian PENAL PRESS}

The Canadian penal press got its tentative beginning with the publication of Vocation (1949-1954), a correctional staff produced publication involving prisoner writers at the Federal Training Centre 
at Laval, Quebec. It was an occasional publication which focused on and lobbied for the new vocational training program being put into place within the federal penitentiary system, and which was already established in this prison. With the permitting of sports programs (1949), largely prisoner organised, there was a tentative encouragement of prison populations to get involved in their own reform and to take some small measure of self-determination in prison life. This led to the creation of a weekly, Sports Bulletin, at Ste. Vincent de Paul in May 1950, the Kingston Penitentiary's Softball Review in the same year, and Sports Week in April 1951 in Dorchester Penitentiary. Similar "joint magazines" may have been published in other penitentiaries at this time, though I have found nothing to that effect. The Collins Bay Diamond (1951-1968) exemplifies the process of their early developments. Commencing as an inside sports magazine in 1950, it became an outside directed penal publication in April 1951, and started taking paid subscriptions in January 1952.

Telescope established the credibility of this endeavour and served as a notice to the penitentiary authorities that penal publications were a positive means of selling the new "humanized reform-oriented prison" they were in the process of trying to create under the leadership of Commissioner R.B. Gibson. Magazines were officially encouraged and financially supported by both the Commissioner's office and senior management. The professional presentation of these publications, the product of vocational print shop programs, spoke highly of the scope and quality of the "new" vocational training component of the "new" penitentiary system. In short, these magazines were a valued means of publicity for the "new" penology, and their large paid subscription lists, advertisers, and country wide distribution assured that the message got across to the public.8 ${ }^{8}$ News media and literary circles responded and gave additional publicity to these unofficial organs. In the 1950s, the Canadian penal press was constantly publishing letters of congratulations and support from Commissioner Gibson and his staff, from the particular institution's administration and the classification staff, and from supportive prisoner aid and voluntary assistance groups.

I am not suggesting that these prison magazines did not represent the voice of the prisoner, as their penal press mandate demanded, and as their logos and mottos suggested. This collaboration of prison editorial staffs and penal administrators was tenuous if somewhat contradictory. Certainly the penological innovations of this era were supported by prison populations, and editorial staff also "had" to meet prisoners' demands and deal with their perceptions of the role and function of the penal press. However, this was a period of optimism 
throughout the penitentiary system, and prisoners were also affected by it and gave tenuous, but real support to the liberalization of the regime (e.g., sports, outside visitors and groups) and to the promise of serious vocational and educational training programs becoming available. So prison editors were supportive of the direction of the new penology in Canada, and came to constitute one of the most important and influential lobbies for its implementation in the federal system. Furthermore, these early editors accomplished even more by consistently presenting a substantial, critical analysis of Canadian criminal-justice and penology. The articles from the penal press in the 1950s constitute an important critical mass of commentary and analysis on penal issues in the formative years of Canada's modern prison complex.

By the late 1950s, the effectiveness of the new reformative and increasingly rehabilitative (i.e., treatment oriented) penology was being questioned. For prisoners the promise of the continued development of vocational and educational opportunities was not being met. Nor was acceptance by and reintegration into civil society of "reformed convicts" forthcoming. By this time prisoners who had "benefited" from vocational training (etc.) were returning to penitentiaries with a different story. Discovering that their vocational and trade credentials were not accepted outside, that stigmatization was as problematic as ever, and that promised employment opportunities did not materialize, they added an important ingredient to the developing cynicism vis-a-vis the new "reformative" penology. And so, the temper and internal social relations within our penitentiaries started to change for the worse. Increasingly, reform programs were used by prison staff and the new parole authorities as a "hoop" through which the convict had to jump to win release. As the rising refrain from front line custodial staff; "The cons are running the joint..." started to have an effect on official and public perceptions, as well as staff actions and, therefore, internal staffprisoner relations, the penal press came under a new, critical scrutiny. The growing internal problems resulting from the "control versus reform" contradiction, spilt over onto the pages of the Canadian penal press. The chummy, positive relationship of editorial staff to the Commissioner's office and prison administrators changed to one focusing on the issue of censorship, and the failure of reform programs (existing as policy) to be actually implemented in the spirit and material manifestation promised. The result was a constant turnover of editorial staff, irregular publication (affecting subscriptions, advertising and distribution) and a lack of consistency in style, form, and content. The tone of the writing reflects the situation, and is more biting, openly critical and oppositional, or muted 
and silenced. The key to keeping this penal press flotilla in the water was their membership in the International Penal Press, and the network's intersubjectively shared conversation over the goals, focus and necessity of the penal press.

By openly discussing their problems, the International Penal Press provided support, answers and strategies for dealing with the changing circumstances of their publications. A fixation with the role of the penal press, and the role and function of the editor and editorial staff is highly characteristic of the Canadian penal press in the 1960s and indicates a number of important factors being addressed. First, as tension rose within the penitentiaries and prisoners increasingly rejected the new penal programs as a fraud masking the traditional goals of domination of the prisoner by the prison complex, the format, style and substance of the prisoners' publications became an important point of contention within prison populations. The population's demand that their magazines more stridently air prisoner's grievances was made in a period when censorship was heavy and administrative demands were largely in contradiction with those of the prisoners. This is played out in the pages of this press with the endless discussion and editorial commentary on the question of tone and content -- bitterness and "crying" charges being countered with exhortations to be positive or to write more substantial critical analysis. Second, the process of penal reform itself slowed in the 1960s, the result of strong custodial staff opposition to a liberalized penal regime and the rehabilitative goal, and of a growing confusion and self-doubt amongst senior management staff of the penitentiary service, and their academic and professional advisors and supporters. In this atmosphere, the penal press was a liability whose previous officially endorsed lobbying activities were now defined as "incessant demands", particularly their lobbying "to continue to move forward" towards the originally stated goals of prisoner reform through training and opportunity, an essentially critical task expressed as front line experience.

By the mid-1960s, the majority of the original Canadian penal publications had ceased publication or were going through their death-throes. In the winter of 1968, The Beacon reported that it was the only publication still operating from a maximum security prison in Canada, and was the last of the original group of publications. It also ceased publication later in that year.

The Canadian penal press is transformed at this moment. Its focus on educating and conversing with the public, its strong identification with the International Penal Press, the regularity and continuity of its publications, its widespread distribution and large readership, and the 
prisoners' positive evaluation of their publications' goals and achievements, disappeared. The lack of the Penitentiary Service's continued financial support and curtailment of outside subscriptions and distribution was justified administratively as the product of the irregularity of penal press publications. Tighter censorship and new rules in the form of Commissioners' Directives pushed prison publications to be much more "joint-oriented", amounting to inside informational newsletters, containing far less substantive writing by prisoners, particularly on criminal-justice and correctional issues. The highly characteristic irregularity of publication (mid-1960s to present), and constant change in format, style, quality and even title, indicate the massive destabilization of prison populations and therefore prison publications, which was taking place at this time. The wholesale classification of prisoners and their redistribution into different types and classes of penitentiaries started seriously in the mid-1960s with the commencement of a major prison construction program. Later, a "rehabilitative system model" was put into place which encouraged, indeed demanded, that prisoners move through the system towards less secure institutions and gradual release through "community corrections": temporary absences, day parole, parole and mandatory supervision. This movement within the prison population was supplemented by the constant use of involuntary transfers. Though there were other important factors in the destabilization of the prisoner community (e.g., the new rehabilitation programs and new prison regimes) and its drift towards a state of social disorganization, it was the constant movement of prisoners which had the most debilitating effect on the editorial continuity and regularity of publication for the Canadian Penal Press. Add to this situation a constant turnover of editorial staff and the closing down of publications because of disputes over institutional censorship and the growing turmoil developing in the larger penitentiaries, and the demise of the Canadian penal press in this period is easily understood.

The exceptional history of Tightwire (1973-1989), the penal press publication of the Kingston Prison for Women, confirms the importance of institutional and editorial stability on the continuity of the penal press. A bi-monthly that started publishing in 1973, it represents the penal press of the past in terms of its consistency of policy, format and quality. It is the only Canadian publication of note which maintained its ties to the International Penal Press network into the 1980s. It presents a consistently critical analysis of Canadian criminal-justice and corrections, and ably addresses the particular problems of women who are caught within the social control bureaucracy. I attribute the stability and consistency of Tightwire to 
the lack of wholesale transfers and constant movement of this prison population (because no other federal facilities exist) and the minimal changes in the internal regime which have occurred. Constant changes in policy and program demands in federal (male) penitentiaries, under the guise of prison and prisoner reform, have contributed strongly to their social disorganization. This has not happened at Kingston Prison for Women, and is reflected in the regularity and quality of Tightwire's sixteen years of continuous publication.9

There were a number of exceptional magazines in the 1970s. The Outlook (1972 - 1989) published from Warkworth Institution is the longest current, continuous publication. I especially enjoy Tarpaper (1971-1980) from Matsqui Institution, with its exceptional graphics and cartoons, and a strong commitment to publish substantive analytical essays on social control issues. Taken collectively, the post 1960s era of Canadian penal publications present a portrait of the changing composition of our federal institutions' populations, their internal social relations and organisation (increasingly disorganization) and the basis for current problems and debates.

The Canadian penal press has experienced something of a resurgence in the 1980s, and once again includes some high quality, outside-directed writing. A new understanding of the penal press has been developing, and its editors have provided it with a new format and style. Of particular note are special group publications, such as the Collins Bay John Howard Society Group's Tocsin (1982-1989) or the "Infinity" Lifer Group's newsletter, The Fallacy of Life (19861989). Special Group publications can be traced back to the 1960s. In 1965, the Jaycee Group at British Columbia Penitentiary commenced publishing Bridgeview (1965-1973?), the first such publication, which concentrated on its club activities and the Jaycee program. Many Native Brotherhood Groups had newsletters and magazines dating back to the 1960s. What is new is the specific and exclusive criminal-justice focus of some of these recent penal press publications. I have traced this strand back to its prototype, QuarterCentury News (1973), the publication of a criminal-justice study and self-help group at Millhaven Penitentiary. It was followed by Odyssey (1978-1982), the magazine of a similar type of group at Millhaven. The latter is a highly critical, analytical and combative publication. Today these special group publications, along with a few more traditional (stable) publications like Tightwire and The Outlook, constitute the core of prisoners' writing on criminal-justice in the penal press. 


\section{a Catalogue of the Canadian Penal Press}

The following catalogue of Canadian publications is not exhaustive, and also contains gaps in the information I have collected on publications listed. The difficulties in documenting and cataloging the Canadian Penal Press are considerable. There are no records of these publications at institutional or headquarters' levels, and no organised collection of any scale exists except my own. Two other large collections are held by the National Library (Ottawa) and the library of the Department of the Solicitor General. Prison disturbances and fires have taken their toll on inside collections, and the lack of facilities to preserve internal collections have added to the problems. The irregularity of publication and constant creation of new magazines (titles) in the 1970s and 1980s add another dimension to locating and mapping their publication. Through a close reading of my holdings, I have been able to identify the dates on which most of these publications commenced, but I have found it much more difficult to ascertain the dates when they ceased publication. Specifics of these lists and of my collection are available upon request. I am interested in contacting anyone who has worked on or with Canadian penal press publications, who might know of other holdings, or who have issues they would be willing to donate to the collection or which I could reproduce.

\section{ATLANTIC REGION}

\section{Dorchester Penitentiary}

\begin{tabular}{|ll|}
\hline Sports Week: & An inside magazine. \\
& Weekly commenced April 12, 1951 \\
& to summer 1951. \\
\hline The Beacon: & An outside directed magazine. \\
& Monthly/bi-monthly commenced \\
& July 1951 to January 1971. \\
\hline The Boomerang: & An outside directed magazine: \\
& series information minimal. \\
& Monthly commenced publication in \\
& June, 1979; date ceased publication \\
& unknown. \\
\hline The Prison Review: & An outside directed magazine; \\
& series information minimal. \\
& Monthly commenced publication \\
& November, 1981 to July, \\
& $1982(?) .10$ \\
\hline The Echo: & A special group magazine of the \\
& Jaycees. Monthly commenced \\
& publication July, 1968 to August, \\
& $1976(?)$. \\
\hline
\end{tabular}




\begin{tabular}{|ll|}
\hline The Dry Road: & A special group magazine of \\
& Alcoholics Anonymous. \\
& Monthly published in 1960; series \\
& information is minimal. \\
\hline Shepody Sampler: & An inside magazine of Dorchester \\
& Farm Annex. \\
& Occasional commenced April, \\
& $1979 ;$ series information minimal. \\
\hline Hill Top Journal: & An inside magazine. \\
& Monthly commenced publication \\
& April 9, 1986 to 1986(?). \\
\hline
\end{tabular}

Springhill Institution

\begin{tabular}{|ll|}
\hline The Communicator: & An outside directed magazine \\
& Monthly commenced publication in \\
& 1972 to $1986(?)$. \\
\hline
\end{tabular}

\section{QUEBEC REGION}

Ste. Vincent de Paul Penitentiary (Laval)

\begin{tabular}{|c|c|}
\hline Sports Bulletin: & $\begin{array}{l}\text { An inside magazine. } \\
\text { Weekly commenced publication } \\
\text { May } 17,1950 \text { to September, } 1951 .\end{array}$ \\
\hline Pen-o-Rama: & $\begin{array}{l}\text { An outside directed magazine with } \\
\text { wide distribution, fully bilingual. } \\
\text { Monthly commenced publication } \\
\text { May, } 1951 \text { to } \\
\text { November/December, } 1968 \text {. }\end{array}$ \\
\hline Exodus: & $\begin{array}{l}\text { An inside magazine in French. } \\
\text { Monthly commenced publication } \\
\text { November, } 1970 \text { to } 1971(\text { ?); series } \\
\text { information minimal. }\end{array}$ \\
\hline Ravon D'Espair: & $\begin{array}{l}\text { An inside magazine in French. } \\
\text { Bi-monthly commenced publication } \\
\text { in October/November, } 1976 \text { to } \\
1977(?) ; \text { series information } \\
\text { minimal. }\end{array}$ \\
\hline L'Optique: & $\begin{array}{l}\text { An outside magazine in French. } \\
\text { Monthly commenced publication in } \\
\text { November, } 1982 \text { to October, } \\
1986(?) \text {. }\end{array}$ \\
\hline \multicolumn{2}{|c|}{ Federal Training Centre (Laval) } \\
\hline Vocation: & $\begin{array}{l}\text { An inside magazine, prison staff } \\
\text { directed, bilingual. } \\
\text { An occasional commenced } \\
\text { publication November, } 1949 \text { to } \\
\text { April, } 1954 \text {. }\end{array}$ \\
\hline
\end{tabular}




\begin{tabular}{|ll|}
\hline Horizons: & An inside magazine in French. \\
& Monthly commenced publication \\
& March, 1956 to December, 1967. \\
\hline
\end{tabular}

\section{Leclerc Institution}

\begin{tabular}{|ll|}
\hline Contact: & $\begin{array}{l}\text { An outside directed magazine, } \\
\text { bilingual. Bi-monthly commenced } \\
\text { publication December, 1961 to } \\
\text { June, 1973(?). }\end{array}$ \\
\hline
\end{tabular}

\section{Archambault Penitentiary}

\begin{tabular}{|ll|}
\hline Pen-Vista: & An outside directed magazine, fully \\
& bilingual. Monthly may have \\
& commenced publication in May, \\
& $1977 ;$ series information minimal. \\
\hline
\end{tabular}

\section{Cowansville Institution}

\begin{tabular}{|ll|}
\hline La Gazette: & An outside directed magazine, in \\
& $\begin{array}{l}\text { French. Occasional commenced } \\
\text { publication in June, 1976 to }\end{array}$ \\
& October, 1976(?). \\
\hline L'Incubateur: & An inside magazine, in French. \\
& Monthly published June, 1979 to \\
& August, 1979; series information \\
& minimal. \\
\hline Le Vendredi 13: & An inside magazine, in French. \\
& Monthly commenced publication \\
& December, 1986 to 1987(?). \\
\hline La Voie Lactee: & An inside magazine, in French. \\
& Monthly published in September \\
& and October, 1987. \\
\hline Libre Exchange: & An inside magazine, in French. \\
& Monthly commenced publication \\
& November, 1987 to present. \\
\hline Le Clairon: & Institution \\
\hline
\end{tabular}

\section{ONTARIO REGION}

\section{Kingston Penitentiary}

\begin{tabular}{|ll|}
\hline K.P. Softball Bulletin: & An inside sports magazine. \\
& Weekly published in 1950 and \\
& 1951 ; series information minimal. \\
\hline
\end{tabular}




\begin{tabular}{|ll|}
\hline Telescope: & An outside directed magazine; \\
& Canada's first subscribed penal \\
& press publication. Monthly \\
& commenced publication September, \\
& 1950 to 1968(?). \\
\hline Changing Times: & An outside directed magazine. \\
& Monthly commenced publication \\
& January, 1974 to 1975; series \\
& information minimal. \\
\hline Key Hole: & An inside magazine. \\
& Bi-monthly commenced publication \\
& AprilMay, 1980 to November, \\
& 1980(?); series information \\
& minimal. \\
\hline
\end{tabular}

\section{Collins Bay Penitentiary}

\begin{tabular}{|ll|}
\hline C.B. Diamond: & Started as an inside sports magazine \\
in 1950, then outside directed & magazine from April, 1951. \\
& Monthly commenced publication \\
& April, 1951 to April, 1968(?). \\
\hline A vatar: & An outside directed magazine. \\
& Monthly commenced publication \\
& June, 1974 to September/October, \\
& 1978 when replaced by \\
& C.O.N.T.A.C.T. \\
& An outside directed magazine. \\
& Bi-monthly commenced publication \\
& October/November, 1978 to \\
& 1981(?). \\
\hline C.O.N.T.A.C.T.: & An inside magazine. \\
& Monthly commenced publication \\
& May, 1986 to present. \\
\hline Ice Carrier: & Ten-plus Fellowship Group \\
& Newsletter. Monthly commenced \\
& publication February, 1970; series \\
information minimal. \\
\hline CONquest: & Newsletter of the "Exceptional \\
& People's Olympiad Committee". \\
& Quarterly commenced publication \\
& Spring, 1978 to present. \\
\hline Olympiad News: & An outside directed magazine of the \\
& John Howard Society Group. \\
& Bi-monthly commenced publication \\
in September/October, 1980. & Occasional from May, 1982 to \\
present.
\end{tabular}




\begin{tabular}{|ll|}
\hline Tribalways Brotherhood Newsletter & $\begin{array}{l}\text { An outside directed Brotherhood } \\
\text { publication. Bi-monthly published } \\
\text { in } 1980 \text { and 1981; series } \\
\text { information minimal. }\end{array}$ \\
\hline Fallacy of Life: & $\begin{array}{l}\text { An outside directed magazine of the } \\
\text { Infinity Lifers' Group. } \\
\text { Occasional commenced publication } \\
\text { October, } 1986 \text { to present. }\end{array}$ \\
\hline Spiritual Newsletter: & $\begin{array}{l}\text { An outside directed religious } \\
\text { magazine. Bi-monthly } \\
\text { commenced 1986(?) to present. }\end{array}$ \\
\hline
\end{tabular}

Joyceville Institution

\begin{tabular}{|ll|}
\hline Joyceville Journal: & An inside magazine. \\
& Monthly commenced publication \\
& April, 1961 to June, 1966. \\
\hline The Advance: & An inside magazine. \\
& Quarterly commenced publication \\
& September, 1966 to Summer, \\
& 1969, occasional through January, \\
& 1979. \\
\hline Pendulum: & Started as an outside directed \\
& magazine, but by 1981 was inside \\
& magazine. \\
& commenced publication March, \\
& 1979, but is only occasional \\
& (numerous stoppages in \\
& publication) to 1987(?). \\
\hline
\end{tabular}

Kingston Prison for Women

\begin{tabular}{|c|c|}
\hline The Voice Inside: & $\begin{array}{l}\text { An outside directed magazine, } \\
\text { previously published under another } \\
\text { title (unknown). Monthly } \\
\text { commenced publication June, } 1971 \\
\text { to } 1972(?) \text {; series information } \\
\text { minimal. }\end{array}$ \\
\hline $\mid \overline{\text { Inside Looking Out: }}$ & $\begin{array}{l}\text { An inside magazine. } \\
\text { Bi-monthly commences in 1972; } \\
\text { series information minimal. }\end{array}$ \\
\hline Tightwire: & $\begin{array}{l}\text { An outside directed magazine. } \\
\text { Bi-monthly commenced publication } \\
\text { in } 1973 \text { (date unknown) to present. }\end{array}$ \\
\hline \multicolumn{2}{|c|}{ Warkworth Institution } \\
\hline The Outlook: & $\begin{array}{l}\text { An inside magazine. } \\
\text { Monthly commenced publication } \\
\text { November, } 1972 \text { to } 1979 . \\
\text { Bi-monthly/occasional } 1979 \text { to } \\
\text { present. }\end{array}$ \\
\hline
\end{tabular}




\begin{tabular}{|c|c|}
\hline Astra News: & $\begin{array}{l}\text { A special group magazine of } \\
\text { Alcoholics Anonymous. } \\
\text { Occasional published in 1983: } \\
\text { series information minimal. }\end{array}$ \\
\hline \multicolumn{2}{|c|}{ Millhaven Penitentiary } \\
\hline Momentum: & $\begin{array}{l}\text { An outside directed magazine. } \\
\text { Bi-monthly, date commenced } \\
\text { publication unknown; published in } \\
\text { 1976; series information minimal. }\end{array}$ \\
\hline Highwitness News: & $\begin{array}{l}\text { An inside magazine. } \\
\text { Monthly commenced publication in } \\
\text { November, } 1983 \text { to March, } 1988 \text {. }\end{array}$ \\
\hline Millhaven Flash: & $\begin{array}{l}\text { An inside magazine. } \\
\mathrm{Bi} \text {-weekly commenced publication } \\
\text { in summer of } 1986: \text { series } \\
\text { information minimal. }\end{array}$ \\
\hline The Partisan: & $\begin{array}{l}\text { An outside directed magazine. } \\
\text { Bi-monthly commenced publication } \\
\text { April/May, } 1988 \text { to present. }\end{array}$ \\
\hline Quarter Century News: & $\begin{array}{l}\text { A special group publication of a } \\
\text { criminal justice and self-help group. } \\
\text { Quarterly commenced publication in } \\
\text { Fall, } 1973 \text { to } 1974 \text {; series } \\
\text { information minimal. First penal } \\
\text { press publication from Millhaven. }\end{array}$ \\
\hline Odyssey: & $\begin{array}{l}\text { A special group publication of a } \\
\text { criminal-justice study and self-help } \\
\text { group. Bi-monthly that } \\
\text { commenced August/ September, } \\
1978 \text { to November 1982(?). }\end{array}$ \\
\hline \multicolumn{2}{|c|}{ Beaver Creek Correctional Camp } \\
\hline The Lodestar: & $\begin{array}{l}\text { An outside directed magazine. } \\
\text { Quarterly commenced publication in } \\
\text { May, } 1965 \text { to winter } 1971 \text {. } \\
\end{array}$ \\
\hline
\end{tabular}

PRAIRIE REGION

Saskatchewan Penitentiary

\begin{tabular}{|ll|}
\hline The Pathfinder: & An outside directed magazine. \\
& The second penal press publication \\
& with subscribers. \\
& Monthly commenced publication \\
& February, 1951 to 1966(?). \\
\hline The New Outlook: & $\begin{array}{l}\text { Series information minimal; } \\
\text { published in late 1970. }\end{array}$ \\
\hline
\end{tabular}




\begin{tabular}{|c|c|}
\hline OFF The Wall: & $\begin{array}{l}\text { An outside directed magazine. } \\
\text { Monthly commenced January, } 1974 \\
\text { to August, } 1977 .\end{array}$ \\
\hline Sounds of Silence: & $\begin{array}{l}\text { Series information minimal. } \\
\text { Possibly started in 1977; known } \\
\text { published in } 1979 .\end{array}$ \\
\hline OFF The Wall: & $\begin{array}{l}\text { An inside magazine. } \\
\text { Monthly uses former title, } \\
\text { commenced publication March, } \\
1986 \text { to } 1987(?) \text {. }\end{array}$ \\
\hline The Vince McLeod Communicator & $\begin{array}{l}\text { Special group publication of } \\
\text { Toastmasters International. } \\
\text { Occasional commenced publication } \\
\text { in } 1977 \text { to December, } 1978 \text {. }\end{array}$ \\
\hline The Inner Voice: & $\begin{array}{l}\text { Special group publication of } \\
\text { Toastmasters International. } \\
\text { Occasional commenced publication } \\
\text { February, 1979; date ceased } \\
\text { publication unknown. }\end{array}$ \\
\hline \multicolumn{2}{|c|}{ Stony Mountain Penitentiary } \\
\hline$\longdiv { \text { Mountain Echo: } }$ & $\begin{array}{l}\text { An outside directed magazine. } \\
\text { Monthly commenced publication } \\
\text { September, } 1951 \text { to May/June, } \\
\text { 1965(?). }\end{array}$ \\
\hline Inside-Outside: & $\begin{array}{l}\text { An inside magazine. } \\
\text { Monthly commenced in } 1968 \text { to } \\
\text { 1969; series information minimal. }\end{array}$ \\
\hline Terminator: & $\begin{array}{l}\text { An outside directed magazine. } \\
\text { Bi-monthly commenced publication } \\
\text { January/February, } 1974 \text { to } 1977(?) \text {. }\end{array}$ \\
\hline Vanguard: & $\begin{array}{l}\text { An inside magazine. } \\
\text { Bi-monthly commenced publication } \\
\text { in } 1979(?) \text { to } 1980(?) \text {; series } \\
\text { information minimal. }\end{array}$ \\
\hline Stony Mountain Flyer: & $\begin{array}{l}\text { An inside magazine. } \\
\text { Monthly commenced publication in } \\
1978(?) \text { to } 1983(?) ; \text { series } \\
\text { information minimal. }\end{array}$ \\
\hline For the Record: & $\begin{array}{l}\text { Series information minimal. } \\
\text { Published in } 1986 \text { and } 1987 .\end{array}$ \\
\hline Terminator: & $\begin{array}{l}\text { An outside directed magazine. } \\
\text { Monthly commenced publication } \\
\text { Spring, } 1988 \text { to present. }\end{array}$ \\
\hline
\end{tabular}




\begin{tabular}{|ll|}
\hline New Dawn: & Special group magazine of \\
& Alcoholics Anonymous. \\
& Quarterly, date commenced \\
& publication unknown; 1953 to 1958 \\
& published, possibly continues in \\
& $1960 \mathrm{~s}$. \\
\hline Native Brotherhood Newsletter: & A special group magazine of Native \\
& Brotherhood. \\
& Occasional commences in Spring, \\
& 1985 to (?); series information \\
& minimal. \\
\hline
\end{tabular}

\begin{tabular}{|ll|}
\hline Tunnel Newsletter: & A special group newsletter of \\
& Omega Lifers' Group; outside \\
& directed. Occasional \\
& commenced publication in March, \\
& 1985 to present. \\
\hline The Justice Group: & A special group magazine of a \\
& criminal-justice study group. \\
& Occasional commenced publication \\
& in Spring, 1987 to present. \\
\hline
\end{tabular}

\section{Drumheller Institution}

\begin{tabular}{|ll|}
\hline Inside News: & An inside magazine. \\
& Weekly commenced publication in \\
& $1972(?)$ to 1975(?). \\
\hline The Quest: & An outside directed magazine; \\
& changes title to Inside News in \\
& January, 1974. \\
& commenced publication in March, \\
& 1973 to December, 1973. \\
& Restarted as monthly, Inside News \\
& January, 1974 to July, 1974. \\
& An outside directed magazine. \\
& Monthly commenced publication in \\
& October, 1974 to 1979(?). \\
\hline Slammer: & An inside magazine. \\
& Published eight times per year \\
& commencing in February, 1984 to \\
& $1985(?)$. \\
\hline
\end{tabular}

\section{Bowden Institution}

\begin{tabular}{|ll|}
\hline Ghost Courier: & An outside directed magazine. \\
& Bi-monthly commenced publication \\
& $1984(?)$ to 1987(?) \\
\hline The Insider: & Series information minimal. \\
\hline
\end{tabular}


PACIFIC REGION

British Columbia Penitentiary

\begin{tabular}{|c|c|}
\hline Transition: & $\begin{array}{l}\text { An outside directed magazine. } \\
\text { Bi-monthly commenced publication } \\
\text { March/April, } 1951 \text { to } 1963(?) \text {. }\end{array}$ \\
\hline Bridgeview: & $\begin{array}{l}\text { A special group magazine of } \\
\text { Jaycees. Monthly commenced } \\
\text { publication April, } 1965 \text { to } 1973(?) \text {. }\end{array}$ \\
\hline Indian Echo: & $\begin{array}{l}\text { A special group magazine of the } \\
\text { Indian Educational Club; outside } \\
\text { directed. Quarterly commenced } \\
\text { Winter, } 1966 \text { to January, 1971(?) }\end{array}$ \\
\hline \multicolumn{2}{|c|}{ Matsqui Penitentiary } \\
\hline Tarpaper: & $\begin{array}{l}\text { An outside directed magazine. } \\
\text { Bi-weekly commenced June, } 1971 \\
\text { to June } 1972 \text {. Becomes monthly in } \\
\text { July, } 1972 \text { to May/June } 1980 \text {. }\end{array}$ \\
\hline Con-notes: & $\begin{array}{l}\text { An inside magazine. } \\
\text { Monthly commenced publication in } \\
1977(?) \text { to } 1978(?) ; \text { series } \\
\text { information minimal. }\end{array}$ \\
\hline Catch-22: & $\begin{array}{l}\text { An inside magazine. } \\
\text { Weekly commenced publication in } \\
\text { 1979(?) to February, 1981(?); } \\
\text { series information minimal. }\end{array}$ \\
\hline Native Echo: & $\begin{array}{l}\text { A special group magazine of the } \\
\text { United Native Club. } \\
\text { Series information minimal; } \\
\text { published in } 1974 \text {. }\end{array}$ \\
\hline \multicolumn{2}{|c|}{ William Head Institution } \\
\hline Out of Bounds: & $\begin{array}{l}\text { An outside directed magazine. } \\
\text { Monthly commenced publication } \\
\text { March, } 1980 \text { to present. }\end{array}$ \\
\hline Indian: & $\begin{array}{l}\text { A special group magazine of Indian } \\
\text { Educational Club; outside directed. } \\
\text { Occasional commenced publication } \\
\text { in October, } 1967 \text { to September, } \\
1969(?) \text {. }\end{array}$ \\
\hline The Messenger: & $\begin{array}{l}\text { A special group magazine of Indian } \\
\text { Educational Club; outside directed. } \\
\text { Occasional commenced publication } \\
\text { in } 1970(?) \text { to } 1972(?) \text {. }\end{array}$ \\
\hline
\end{tabular}




\section{Mountain Institution}

\begin{tabular}{|c|c|}
\hline Con-versely: & $\begin{array}{l}\text { An outside directed magazine. } \\
\text { Monthly commenced publication in } \\
\text { Spring, 1976; series information } \\
\text { minimal. }\end{array}$ \\
\hline OFF The Wall: & $\begin{array}{l}\text { An outside directed magazine. } \\
\text { Series information minimal; } \\
\text { commenced publication May, } 1981 .\end{array}$ \\
\hline The Mountaineer: & $\begin{array}{l}\text { An inside magazine. } \\
\text { Monthly commenced publication } \\
\text { June, } 1983 \text { to (?). }\end{array}$ \\
\hline
\end{tabular}

Mission Institution

\begin{tabular}{|ll|}
\hline Scrapaper: & An outside directed magazine. \\
& Bi-monthly probably commenced \\
& publication November/December, \\
& 1976 to $1980(?)$. \\
\hline Mission Weekly: & An inside newsletter. \\
& Weekly commenced publication \\
& April, 1980 to June 27, 1980. \\
& An inside magazine. \\
& Bi-weekly commenced publication \\
& July 4, 1980 to August 1, 1980. \\
\hline Mission Pooper Paper: & An inside magazine. \\
& Bi-weekly commenced publication \\
& September 1, 1980 to November, \\
& 1983(?). \\
\hline Mission Medium: & Commences as inside magazine. \\
& Monthly commenced publication \\
& June, 1985 to August, 1986. Then \\
& becomes bi-monthly outside \\
& directed literary magazine to \\
& Summer, 1987(?). \\
\hline
\end{tabular}

\section{Kent Penitentiary}

\begin{tabular}{|ll|}
\hline Cemetery Road: & An outside directed magazine. \\
& Monthly commenced publication in \\
& Spring, 1981(?) to 1985(?). \\
\hline Kent Times: & An outside directed magazine. \\
& Bi-monthly commenced publication \\
& in August, 1986 to 1988(?). \\
\hline
\end{tabular}




\section{NOTES}

1. The latter is of particular note, having been started through the financial contributions and editorial support of a group of prisoners which included three of the infamous Younger Brothers, Cole Younger playing a major role in its production (See Baird, 1967).

2. To try and offset this problem we have recently started this new publication, the Journal of Prisoners on Prisons which presents the analysis of prisoners and former prisoners on various aspects of criminal-justice and corrections.

3. Art Solomon, an Ojibwa spiritual leader and elder, has devoted the last two decades to establishing Native religious rights in Canada's prisons. He has twice been awarded honorary doctorates from Canadian universities, is a member of the International World Council of Churches Steering Committee, and a central figure in the International Prison Abolition movement.

4. Penal exchange columns were featured in most penal publications throughout the 1950s and 1960s. They served as a means of recognition, comaraderie and censorship, and as a way to carry on internal debates and to maintain contact.

5. See for example; Vladimir Nekrassoff, "About Penitentiaries: A Review of Trends and Ideas", in Pen-o-Rama October 1961, Ste. Vincent de Paul Penitentiary.

6. Blackstock, Hjalmarson and Reid have published commercial books on prison and their lives, while Frank Guiney has written the best historical pieces on prison life and its subculture that I have encountered in the pages of the penal press. He has also been the recipient of numerous awards for his poetry.

7. See for example, E.S. Gardner's articles in his column "The Court of Last Resort" in Argosy magazine throughout the 1950s. His pieces such as "The Importance of the Penal Press" were reprinted by many of the Canadian penal press publications.

8. Note that institutional financial support, large paid subscribers lists, and advertisers allowed publications to be distributed free to many media outlets and professionals working within the criminal-justice system.

9. For a current commentary on Kingston Prison for Women, see J. Mayhew (1988).

10. The irregularity of publication should be noted. This listing provides overall publishing dates. The inclusion of a (?) indicates exact date unknown; in all other instances dates have been verified. My current collection holdings include approximately 1,300 issues of the publications listed.

\section{REFERENCES}

Adelberg, E. and Currie, C. (eds.) (1987) Too Few To Count. Vancouver: Press Gang.

Baird, R. (1967) The Penal Press. Evanston: Northwest University Press.

Blackstock, H. (1967) Bitter Humour. Toronto: Burns and MacEachern.

Caron, R. (1978) Go Boy. Toronto: McMillan.

Caron, R. (1984) Bingo. Toronto: McMillan. 
Dobbin, M. (1981) The One-And-A-Half Men. Vancouver: Newstar Books.

Franklin, H. B. (1978) The Victim as Criminal and Artist. New York: Oxford Press.

Gaucher, R. (1982) Class and State in Lower and Upper Canada. Sheffield: Unpublished Ph.D.

Gaucher, R. (1987) "Canadian Civil Society, the Canadian State and Criminal Justice Institutions: Theoretical Considerations." In R. Ratner and J. McMullan (Eds.), State Control: Criminal Justice Politics in Canada. Vancouver: University of British Columbia Press.

Hjalmarson, G. (1961) Just Call Us Bandits. Toronto: Longmans.

Lefebvre, G. (1949) The Coming of the French Revolution. Princeton: University Press.

Mayhew, J. (1988) "Corrections is a Male Enterprise." Journal of Prisoners on Prisons. 1:1

Reid, S. (1986) Jack Rabbit Parole. Vancouver: Pluto.

Rude, G. (1970) Paris and London in the 18th Century. London: Collins. 